\title{
11. How tying funding to 'good behaviour' hits critical NGOs
}

\author{
ANDREW HEWETT \\ Oxfam Community Aid Abroad
}

$\mathrm{R}$ ECENTLY, The Australian headlined an article by Dennis Shanahan: 'Howard tightens screws on charities'. Shanahan's article outlined 'a right-wing think tank to study charities, welfare and aid groups... in a bid to introduce new rules on access to government departments based on competence and "acceptability" to the Coalition'.

In a separate box beside the article, nine agencies were listed as being particular targets of the IPA. My agency, Oxfam Community Aid Abroad, was paid the backhanded compliment of heading this list that also included such 'radical' and 'dangerous' organisations like the Red Cross, World Vision and the World Wide Fund for Nature.

The 'right wing' organisation referred to by Shanahan was the Institute for Public Affairs and the study that they are undertaking is but the latest stage in a concerted campaign they are conducting against NGOs and charities.

Charities and NGOs are facing a number of challenges. As well as the work of the IPA, we are also coming to grips with draft legislation introduced by Federal Treasurer Peter Costello defining charities, a tightening of federal funding of NGOs and charities and the Government's promotion of a Not-forProfit Council. This latter initiative, well-funded as it is, can only be seen as a very specific challenge to ACOSS.

I am focusing on the impact of the charities legislation and the work of the IPA. I'll seek to outline the nature of the attacks and their possible consequences. I'll try to place these developments in an international context. And I'll suggest some possible reasons for why these attacks are happening now. 


\section{The charities legislation}

At the outset, I should for the public record make clear that Oxfam Community Aid Abroad wants a clearing up of the regulatory environment for charities and NGOs. We're subject to nine different jurisdictions, often with contradictory or inconsistent requirements, massive compliance costs and confusion. A number of years ago one large agency calculated that it spent more than $\mathrm{A} \$ 1$ million a year complying with the various Government requirements. For a number of years we've called for a National Charities Commission, which would help ensure good governance, ethical practices and efficient management of the rapidly growing non-government or charitable sector.

But we also want this national regulatory environment to be based on a contemporary understanding of the role and work of charities and nongovernment organisations. This includes a recognition that charities seek to achieve their charitable purpose through a wide variety of means including direct service provision and advocacy for changes in policies and practices that sustain poverty and injustice.

The Treasurer's draft legislation badly misses the mark and would lead to a silencing - or at least the intimidation - of many important voices. The origins of this draft legislation date back to the GST deal between the Government and the Australian Democrats. As part of the sweetener for their support for the GST, the Democrats insisted upon a Government enquiry into the definition of charities. By extension this would assist with the taxation treatment of charities.

Such an enquiry was established and following many months of deliberation and consultation came forward with recommendations, which seemed to understand this contemporary role of charities. It gave full regard to the centrality of advocacy for many, if not most, contemporary charities. And implicitly it understood that this role was supported by donors and the broader Australian community.

Many months after this report was published Costello brought forward his draft legislation. Ignoring the finding of his own Government's inquiry, this legislation has placed a large question mark around the role - and legitimacy - of advocacy by charities.

It effectively outlaws activities by charities which 'seek to change the law or government policy' or 'advocate a cause' if they are more than 'ancillary or incidental to the dominant purpose' of the charity. No definition is given of 'ancillary' or of 'incidental'. Is it a proportion of expenditure or of income? Is 


\section{THE PUBLIC RIGHT TO KNOW}

the amount of staff resources? Or what?

This sort of approach stands in stark contradiction to much of stated Government policy, especially their stated aims and objectives of the overseas aid programme. One of the five key themes of the Australian Government's aid programme is governance which is defined as 'promoting democratic and accountable government and effective public administration'.

The Federal Government has actively welcomed, indeed encouraged, advocacy interventions by NGOs and charities. Oxfam Community Aid Abroad's work on reforming the rigged rules and double standards afflicting world trade has led to us being described as a 'key non government ally' in the Government's efforts for agriculture trade reform. Similarly NGO observers have been welcomed on Government delegations to international conferences, most recently to the World Trade Organisation conference in Cancun. NGOs have worked closely with the Australian Defence forces on the development of doctrine to guide military personnel in their interactions with civilians and humanitarian agencies when overseas.

All these sorts of activities are at risk with this draft legislation. Currently the Taxation Board is consulting on this draft legislation. The noises from this process seem to be positive but the next two months will tell.

\section{The role of the IPA}

And then there is the IPA. First, who are they and why don't they like my organisation and others like us? The IPA was founded some 60 years ago. Its first chief executive was a man by the name of Charles Kemp - yes, the father of David and Rod. Charles Kemp was associated with the IPA for many years. The IPA was a child of the Cold War and for many years was essentially a big business education, lobbying and campaigning group.

With the end of the Cold War it enthusiastically embraced a Thatcherite agenda of privatisation, deregulation and small government.

It is well connected to both Government and the media and is very adept at getting its message across. Its staff regularly appear in the opinion pages of the Australian media and its influence can be seen in the columns of people like Miranda Devine, Andrew Bolt and Janet Albrechststein. The chair of its board is Alan Stockdale, formerly Treasurer in the Kennett Government and other board members include men - and I use that word advisedly as their board and research committee are all-male affairs while there is one, recently appointed, woman listed among its staff - with close connections to the mining and 180 PACIFIC JOURNALISM REVIEW 10 (1) 2004 
biotechnology industries as well as companies with strong interests in Indonesia.

In 1999, the IPA established an NGO Unit which is headed by former Keating Government Minister Gary Johns. Its major focus appears to be the legitimacy and standing of NGOs in respect to policy making. It has repeatedly urged the Federal Government to withdraw financial and other support provided to NGOs that advocate around matters such as social, industrial and environmental standards. The view has been put that NGOs receiving public money must fully support Government values and objectives. There is no place for dissent.

Johns and others from the IPA argue that democratic governments, otherwise answerable to their electors, are failing under pressure from interest groups. This leads to an erosion in public confidence in government and institutions of representative democracy. This is a result of a 'particularly boisterous and highly organised civil society'.

Johns further argues that NGOs et al depoliticise life - 'making it less amenable to public dispute'. So much for the contribution of NGOs to stimulating, informing or facilitating public debate.

Somewhat in contradiction to the IPA's general adherence to free-market orthodoxy, Johns proposes a highly elaborate system of regulation for NGOs wishing to have any contact with government. NGOs would be obliged to provide detailed information about governance, representativeness, financial accountability, fund-raising and expertise.

The IPA is well-connected. It has been commissioned by the Federal Government's Department of Family and Community Services to study NGOs' relationship with government. This study - worth some $\$ 50,000$ - is due to be completed by the end of 2003 . Why it is taking so long is a mystery - its conclusions could have been written many months ago.

The IPA's efforts over the years have already had an impact. In my sector it has a direct influence on Federal Government funding of NGOs, leading to an increasing number of restrictions on where government funds can be used and for what sort of development programmes. I would also argue that its attacks on NGOs working in or on Indonesia have enhanced the security risk to members of those agencies.

In the light of these developments, I, for one, am very pleased-and relieved - that less than ten per cent of Oxfam Community Aid Abroad's income comes from the Australian Government.

PACIFIC JOURNALISM REVIEW 10 (1) 2004181 


\section{The global context}

These attacks in Australia are mirrored in other countries - most obviously in the United States. In June 2003, the IPA joined with the American Enterprise Institute to hold a conference on the growing power of international NGOs. Like the IPA, the AEI is very well connected, probably even more so. More than 20 AEI staff are now working for the Bush administration and more than 40 Administration officials attended the AEI function. Like the IPA, the AEI has now launched its own website - www.NGOWatch.org.

In a similar vein, Andrew Natsios, the head of USAID, the US Government's aid agency has recently attacked development NGOs, publicly complaining that US NGOs providing humanitarian assistance in Iraq and Afghanistan were not making it sufficiently clear that they were 'arms of the US Government'. He is supported by Newt Gingrich who argues that the 'United States needs to communicate effectively.... the rise of a global anti-American network of activists and nations - including left-wing non-government organisations, elite media and most of the elite academies around the world further increases the country's need for a comprehensive communication and information strategy'.

So why are these attacks occurring?

I would like to suggest five main reasons that are all very much interconnected:

- First, there is the growing influence of NGOs. We are seen to be credible contributors to public debate and have an increasing influence in public policy decision-making. Non government development agencies like mine help bring the voices and experiences of the poor and marginalised to public forums. It is no coincidence that the United Nations Secretary General has established a high level panel headed by former Brazilian President Cardoso to look at enhancing the role of civil society.

- Secondly, the focus of much of this advocacy is directed towards the role of the private sector. As a development agency, Oxfam Community Aid Abroad recognises the increasingly important role that the private sector can play in development. We work with major companies which are seeking to make a positive contribution to development. But we have no hesitation in calling bad behavior by large corporations. This can bring us, for instance, in conflict with some of the major financial backers of groups like the IPA and AEI. 
- Thirdly, NGOs have high public standing, especially compared to the private sector and governments. Virtually every public opinion poll on the issue shows that NGOs have high public standing and credibility. This strengthens our advocacy and our contribution to public debate. Conversely anything that weakens our credibility reduces the impact of our advocacy.

- Fourthly, while it is at an early stage, NGOs are helping build a new form of global inter-action. This has implications for current arrangements of global governance and directly challenges the approach of those who are currently seeking to undermine what governance there is at a global level.

- Finally, and not insignificantly, I think NGOs are modelling a different and clearly an attractive means of social organisation. We all know that identification with political parties is declining in this country and elsewhere, alongside an increasing alienation from the formal political process. But meanwhile agencies like mine are reporting record growth in income and supporters. The number of pledge donors we have, for instance, has trebled in the last two years.

NGOs have a vital role to play in public debate. We can help bring the voices and experiences of the people we work with into decision-making and into the national conversation. Limiting, or closing down our role hurts Australian public life, decision-making and most importantly hurts some of the poorest people on this earth.

Andrew Hewett is Executive Director of Oxfam Community Aid Abroad. He presented this address, 'Tying funding to 'good behaviour': Threats against critical NGOs and community organisations', at the third Public Right to Know (PR2K3) conference at the University of Technology, Sydney, 17-19 October 2003. andrewh@caa.org.au 